\title{
Hybridization of banteng (Bos javanicus) and zebu (Bos indicus) revealed by mitochondrial DNA, satellite DNA, AFLP and microsatellites
}

\author{
IJ Nijman ${ }^{1,2}$, M Otsen ${ }^{1}$, ELC Verkaar ${ }^{1}$, C de Ruijter ${ }^{1}$, E Hanekamp $^{1}$, JW Ochieng ${ }^{3}$, S Shamshad ${ }^{4}$, \\ JEO Rege ${ }^{5}$, O Hanotte ${ }^{3}$, MW Barwegen ${ }^{6}$, T Sulawati ${ }^{7}$ and JA Lenstra ${ }^{5}$ \\ ${ }^{1}$ Institute of Infectious Diseases and Immunology, Faculty of Veterinary Medicine, Utrecht University, Yalelaan 1, 3584 CL Utrecht, The \\ Netherlands; ${ }^{2}$ Institute of Equine Sciences, Faculty of Veterinary Medicine, Utrecht University, Yalelaan 1, 3584 CL Utrecht, The \\ Netherlands; ${ }^{3}$ International Livestock Research Institute, P.O. Box 30709, Nairobi, Kenya; ${ }^{4}$ National Institute of Animal Biotechnology, \\ Jerantut 27000, Pahang D.M., Malaysia; ${ }^{5}$ International Livestock Research Institute, P.O. Box 5689, Addis Ababa, Ethiopia; ${ }^{6}$ Royal \\ Institute of Linguistics and Anthropology, Reuvensplaats 2, 2300 RA Leiden, The Netherlands; ${ }^{7}$ Animal Reproduction Laboratory, \\ Animal Husbandry Faculty, Brawijaya University, Malang, Indonesia
}

\begin{abstract}
Hybridization between wild and domestic bovine species occurs worldwide either spontaneously or by organized crossing. We have analysed hybridization of banteng (Bos javanicus) and zebu (Bos indicus) in south-east Asian cattle using mitochondrial DNA (PCR-RFLP and sequencing), AFLP, satellite fragment length polymorphisms (SFLP or PCR-RFLP of satellite DNA) and microsatellite genotyping. The Indonesian Madura zebu breed is reputed to be of hybrid zebu-banteng origin, but this has never been documented and Bali cattle are considered to be a domesticated form of banteng. The banteng mitochondrial type was found in all animals sampled on the isle of Bali, Indonesia, but only in $35 \%$ of the animals from a Malaysian Bali-cattle population.
\end{abstract}

The Madura animals also carried mitochondrial DNA of either zebu and banteng origin. In both populations, zebu introgression was confirmed by AFLP and SFLP. Microsatellite analysis of the Malaysian Bali population revealed for 12 out of 15 loci screened, Bali-cattle-specific alleles, several of which were also found in wild banteng animals. The tools we have described are suitable for the detection of species in introgression studies, which are essential for the genetic description of local breeds and the preservation of their economic and cultural value.

Heredity (2003) 90, 10-16. doi:10.1038/sj.hdy.6800174

Keywords: Bali cattle; Madura; banteng; hybridization; AFLP; SFLP

\section{Introduction}

Hybridization between species may occur if closely related species share an overlapping habitat or through human intervention during captive breeding. Hybrid offspring may combine desired properties of the parental species, but fertility is often restricted to the homogametic sex (Forsdyke, 2000). This can be overcome by repeated backcrossing to animals from one of the parent species until a viable hybrid population is established. Uncontrolled hybridization, as it occurs in nature, may have had a significant impact on the formation of domestic breeds, but can also affect the genetic integrity of domestic and wild species. Monitoring the species composition of these animals may become essential for the future preservation of genetic diversity.

Within the group of the Bovini, comprising cattle-like species, several hybrids have been described: yakows (Felius, 1995; Tumennasan et al, 1997), a cross of yak (Bos grunniens) and taurine cattle; the selembu, a cross of

Correspondence: IJ Nijman, Faculty of Veterinary Medicine, Utrecht University Yalelaan 1, 3584 CL Utrecht, The Netherlands.

E-mail:I.Nijman@vet.uu.nl

Received 22 July 2002; accepted 3 August 2002 gayal (Bos gaurus) and zebu or the North-American beefalo, a cross of bison (Bison bison) and taurine cattle. In Africa, introgression of Indian zebu bulls (Bos indicus) in taurine herds occurs and has improved the tolerance of the cattle (Bos taurus) to hot and dry environments (Epstein, 1971; Bradley et al, 1994, 1996; Loftus et al, 1994b; Frisch et al, 1997; Hanotte et al, 2000). Bongso et al (1988) described a spontaneous hybridization of wild gaur and zebu.

The domestication of the banteng (Bos banteng) is likely to have occurred either in Java or on mainland southeast Asia, and later the domesticated variety was spread and bred (Rollinson, 1984). Bali cattle are a domesticated form of banteng and are kept throughout Indonesia and Malaysia. This breed is of considerable economic importance since it is adapted to poor-quality fodder, yields good-quality meat and provides draft power. Their small posture makes them particularly suitable for training and work in small- and irregular-shaped fields (Rollinson, 1984). Although the presence of zebu cattle on the island of Bali has been forbidden since 1913 (Felius, 1995), biochemical polymorphisms suggested that zebu and possibly taurine introgression might have occurred (Namikawa, 1981). Furthermore, Bali cattle may have been crossbred to zebu animals outside their region 
of origin. The Madura breed, which on the island of Madura is used for the traditional bull racing competition (kerapan sapi, Felius, 1995), is believed to be a cross between wild banteng or Bali cattle and zebu, originating approximately 1500 years ago (Payne and Rollinson, 1976), but this has never been documented. Hybridization of banteng and zebu is supposed to have occurred in other Indonesian breeds, either spontaneously or via breeding (Epstein, 1971; Felius, 1995). Zebu introgression is considered as a threat of the genetic purity of the endangered wild banteng (Epstein, 1971).

However, the supposed zebu-banteng hybridization has never been verified by genome analysis. Several DNA markers are now available to analyse the genetic background of hybrid Bovini. Mitochondrial DNA (mtDNA) markers reveal introgression via the maternal lineage (Loftus et al, 1994a; Ward et al, 1999; Verkaar et al, 2003). The species origin of the nuclear genome can be inferred from species-specific microsatellite alleles (Frisch et al, 1997; MacHugh et al, 1997), AFLP patterns (Vos et al, 1995; Savelkoul et al, 1999; Buntjer et al, 2002) or mutations in satellite DNA. Previously, we showed that satellite fragment length polymorphism (SFLP), as well as amplified fragment length polymorphisms (AFLP) correlated with introgression of zebu (Bos indicus) in African cattle populations (Nijman et al, 1999). In this paper, we demonstrate the use of mitochondrial D-loop and cytochrome- $b$ typing, AFLP, SFLP and microsatellite genotyping in order to detect zebu-banteng hybridization in Madura and Malaysian Bali cattle.

\section{Materials and methods}

\section{DNA samples}

Tissue (skin) and six blood samples from Madura cattle were collected at local slaughterhouses on Madura, Indonesia and preserved in preservation buffer $(4.5 \mathrm{M}$ $\mathrm{NaCl}, 25 \%$ DMSO) until DNA purification with SDS, proteinase $\mathrm{K}$ and phenol. A mixed blood sample of three Madura bulls was obtained at the scene of the bull racing with permission of the owners. Blood samples of $17 \mathrm{Bali}$ cattle were taken from animals in the south and east of the Malaysian peninsula and from 11 individual Bali cattle of the Indonesian isle of Bali. DNA was isolated from the whole blood using standard SDS/proteinase $\mathrm{K}$ methods and phenol/chloroform extractions (Sambrook et al, 1989). Dr DG Bradley (Dublin, Ireland) kindly donated two zebu DNA samples (Indian Sahiwal breed, pure Bos indicus). DNA from four bantengs was isolated from liver tissue obtained from Blijdorp zoo (Rotterdam, The Netherlands) as described above. Microsatellite genotypes were compared with data from three Indian zebu breeds (Nelore, Ongole and Sahiwal, $n=97$ ) and three European taurine breeds (Jersey, Friesian and Charolais, $n=103$ ).

\section{Analysis of mtDNA}

A fragment of the mitochondrial D-loop was amplified from $50 \mathrm{ng}$ template DNA with the primers D-loopL (5'-AAAAATCCCAATAACTAACACAG-3'; positions 15848-15870) and D-loop-R (5'-TACAATAGATGCTCCGGGTCAG-3'; 126-105), both derived from bovine mtDNA (Genbank J01394) in a standard PCR reaction (50ng primers, $1.5 \mathrm{mM} \mathrm{MgCl}_{2}, 0.2 \mathrm{mM}$ dNTPs and $1.25 \mathrm{U}$ Taq polymerase (Promega) with the following pro- gramme: predenaturation for $2 \mathrm{~min}$ at $92^{\circ} \mathrm{C}, 30$ cycles of $15 \mathrm{~s}$ at $92^{\circ} \mathrm{C}, 45 \mathrm{~s}$ at $52^{\circ} \mathrm{C}$ and $45 \mathrm{~s}$ at $72^{\circ} \mathrm{C}$ ). Products were separated in $1 \%$ agarose gels in $1 \times \mathrm{TAE}, \mathrm{pH} 8$. The excised fragments were purified with the QIAquick system (Qiagen, USA) and inserted in the pGem-T Easy vector (Promega, USA) by following the protocols of the manufacturers. Clones were purified with the Qiagen Midipep kit and sequenced using the Cy5-labelled T7 and SP6 primers and an ALF automatic sequencer (Amersham-Pharmacia Biotech). For each species, sequences were based on the analysis of two independent clones and aligned by the program Bioedit (Hall, 1999). For comparison, a D-loop sequence from zebu (Genbank AF13114610) and one from taurine cattle (AF3114579) were retrieved from the database. The banteng, Bali and Madura sequences have been submitted to Genbank (accession codes AF162486-AF162490). Amplification of the mitochondrial cytochrome $b$ gene and diagnostic digestions with Hinf I (present in zebu, absent in banteng) and Taq I (absent in zebu, present in banteng) has been performed as described previously (Meyer et al, 1995; Verkaar et al, 2002).

\section{PCR-RFLP on satellite DNA}

Fragments from bovine satellite IV DNA were amplified as described previously (Jobse et al, 1995; Nijman and Lenstra, 2001). One-fifth of the PCR product was digested twice with $5-10 \mathrm{U}$ of Ban II (at $37^{\circ} \mathrm{C}$ ), Mse I (at $37^{\circ} \mathrm{C}$ ) or the Mse I isoschizomer Tru 9 (at $65^{\circ} \mathrm{C}$ ) for $3 \mathrm{~h}$ and fractionated on a $2 \%$ agarose gel. As a second digestion did not alter the restriction patterns, we considered the digestion to be complete. DNA was transferred onto a nylon membrane (Amersham) by standard Southern blotting protocols and fixed with UV radiation. After prehybridization for $1 \mathrm{~h}$, filters were hybridized to ${ }^{32} \mathrm{P}$ labelled PCR product of Bos indicus and washed twice for $10 \mathrm{~min}$ in $1 \times$ SSPE and $0.1 \%$ SDS, all steps being carried out at $55^{\circ} \mathrm{C}$. Hybridization was detected by autoradiography on a Molecular Dynamics 400 phosphorimager set at $176 \mu \mathrm{m}$ and $680 \mathrm{~V}$. Quantitative hybridization signals were measured with the Imagequant software (Molecular Dynamics, version 3.22) and results calculated relative to the total signal (amount of DNA) in the gel lane.

\section{AFLP, scoring and interpretation}

AFLP analyses were basically carried out as described (Vos et al, 1995). Briefly, $250 \mathrm{ng}$ DNA of two banteng, two zebu, three Bali and one Madura animal was digested with Taq I and EcoR I (Promega) successively in the buffer supplied by the manufacturer. Taq I and EcoR I adapters (Ajmone-Marsan et al, 1997) were ligated to the fragment ends and after preamplification with E01L and T01, separate AFLP reactions were performed using the primer combinations: E31/T39, E34/T45 and E31/T42 (Table 1). The primers E31 and E34 were end-labelled by using T4 polynucleotide kinase and $\left[\gamma-{ }^{33} \mathrm{P}-\mathrm{ATP}\right]$ and AFLP products were separated on $5 \%$ polyacrylamide gels. Bands were scored as dominant markers using the program Cross Checker (Buntjer and Otsen, 2000) to generate 1 (presence)/0(absence) matrices. These data sets were analysed by the program NTSYS (Rohlf, 1993). Jaccard similarity values (number of shared bands divided by the total number of bands in either species) 
Table 1 Nucleotide sequences of AFLP primers

\begin{tabular}{ll}
\hline Name & \multicolumn{1}{c}{ Sequence $\left(5^{\prime}-3^{\prime}\right)$} \\
\hline E01L & AGACTGCGTACCAATTCA \\
T01 & GATGAGTCCTGACCGAA \\
E32 & GACTGCGTACCAATTCAAC \\
E35 & GACTGCGTACCAATTCACA \\
T32 & GATGAGTCCTCACCGAAAC \\
\hline
\end{tabular}

were calculated and visualized by principal coordinate analysis (PCOORD, Jackson, 1991).

\section{Microsatellite analysis}

Fifteen autosomal microsatellites were genotyped including nine microsatellites (ILSTS005, ILSTS006, ILSTS008, ILSTS023, ILSTS028, ILSTS033, ILSTS036, ILSTS50 and ILSTS103) that were originally isolated from N'Dama taurine cattle (Kemp et al, 1995), and six microsatellites that are commercially available (TGLA122, TGLA126, TGLA227, MGTG4B, AGLA293 and TGLA48 Applied Biosystems StockMark Kit 1). Analyses were carried out as described (Hanotte et al, 2002).

\section{Results}

\section{Mitochondrial DNA analysis}

Figure 1 shows an alignment of the D-loop sequences obtained from a Madura cow, one Malaysian Bali individual and one banteng with taurine and zebu sequences for reference. The banteng sequence is clearly distinct from the zebu and taurine sequences with several point mutations, deletions, insertions and an expanded repeat-like structure (510-550 bp, see Figure 1 ). The Bali sequence is nearly identical $(99.5 \%)$ to the zebu sequence, while the Madura sequence is nearly identical (99.7\%) to banteng. However, PCR-RFLP analysis of the other samples revealed in both breeds the mitochondrial type of either banteng or zebu. From the Madura breed, four animals carried the banteng mtDNA type and three the zebu variant while in a mixed blood sample from three Madura bulls, both zebu and banteng cytochrome $b$ variants were detected (not shown). Analysis of Malaysian Bali samples revealed that 11 out of 17 samples were from maternal zebu origin (Figure $4 b$ and $c$ ), while no zebu patterns were found in the 11 animals sampled on the isle of Bali (not shown).

\section{Satellite DNA polymorphisms}

Sequence analysis of satellite IV DNA (Nijman and Lenstra, 2001) revealed a heterogeneity (TTMA; $M=C$ or A) that creates an Mse I site (TTAA) in part of the repeat units of banteng, while the zebu sequence (TTCA) on the same position is almost homogeneous. Conversely, a GAGCTC Ban II site in zebu is replaced by GAGCTM in banteng. This allows an estimation of the species composition by SFLP or RFLP analysis of satellite DNA (Nijman et al, 1999; Nijman and Lenstra, 2001). The SFLP patterns of both Madura samples are clearly intermediate between the zebu and banteng patterns: Mse I digests (Figure 2a) reveal the presence of banteng-like repeat units, while Ban II digests (Figure 2c) show that the zebulike units are also present. The patterns of two Bali cattle are different, but again both restriction enzymes generate intermediate patterns, suggesting the presence of both zebu and banteng satellite DNA in Madura and Bali cattle. To quantify the presence of the satellite units of zebu and banteng, band intensities were measured by transferring the DNA to nylon membrane and hybridizing to a satellite IV probe. The intensities of the smaller restriction fragments, indicative of the specific restriction site, were measured relative to the total amount of DNA (Figure $2 \mathrm{~b}$ and $\mathrm{d}$ ). Both the Mse I and Ban II digestions indicate that Madura is mostly like zebu, but apparently contains a banteng component, while Bali cattle has a smaller zebu component. Analysis of more Malaysian Bali samples by SFLP with Mse I (Figure 4a) and Ban II (not shown) confirmed a variable degree of zebu introgression, which, however, did not correlate strictly with the origin of the mitochondrial DNA (Figure $4 b, c)$.

\section{AFLP}

AFLP similarities were based on 120 variable markers and were condensed in a PCO plot (Figure 3). Although only one Madura sample was suitable for AFLP analysis, Madura, as well as Bali cattle, have PCO coordinates intermediate between zebu and banteng with Bali cattle closer to the banteng position (Figure 3). The difference between the Bali individuals, as observed by SFLP, is also apparent from the AFLP data.

\section{Microsatellite analysis}

Malaysian Bali individuals were also analysed with 15 microsatellites and the allele frequencies were compared with the frequencies in a group of European taurine, banteng and zebu cattle (data available on request). The microsatellites were highly polymorphic in all breeds (number of detected alleles ranging from 5 -TGLA48- to 21 -TGLA122), with a few exceptions: ILSTS008 and MGTB4b were monomorphic in the banteng samples only, while TGLA227 was monomorphic in banteng but showed low polymorphism in zebu. Although the banteng sample size was probably insufficient to detect the full range of alleles, Malaysian Bali specific alleles were obtained for nine loci (AGLA293, ILSTS005, ILSTS023, ILSTS028, ILSTS050, ILSTS103, MGTG4b, TGLA048 and TGLA227). Predominant Bali alleles are mostly shorter (AGLA293, ILSTS005, ILSTS008, ILSTS023, MGTG4b, TGLA126 and TGLA227), while some are longer (TGLA48, ILSTS103) than the taurine and indicine alleles. The Bali alleles of ILSTSO50 and ILSTS036 differed one base pair in length from the zebu or taurine alleles. Several banteng animals share Bali-cattle-specific alleles, including the alleles of ILSTSO36 with the 1-bp difference. In fact, in four loci (MGTG4b, ILSTS008, TGLA126 and TGLA227), the banteng alleles are only found in Bali cattle.

\section{Discussion}

We have shown that mtDNA, SFLP, AFLP, as well as microsatellites, are informative for the detection of zebubanteng hybridization. Both Madura and Malaysian Bali cattle individuals have a mixed banteng-zebu origin, while no zebu introgression has been found in the individuals from the isle of Bali. 
taurine TACAATAGATGCTCCGGGTCAGGGCCTTIGACGGCCATAGCTGAGTCCAAGCATCCCCCAAAATAAAAAAATACCAAATGMATGACAGCACAGTTATGTGTGAGCATGGGCTGATTAGCCATTAGTCCATCGAGATGTCTTATTTABGA

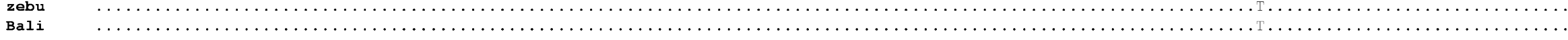

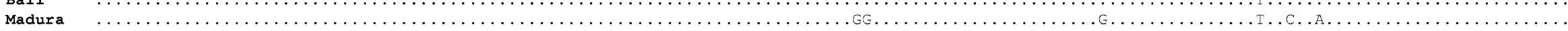

banteng

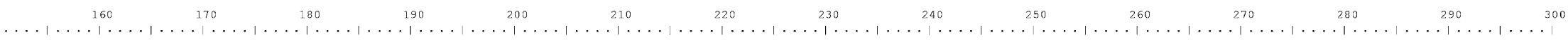

taurine GAAAGAATGGACCGTTTAGATGAGATGGCCCTGAAGAAAGAACCAGATGCCTGGTAAAATTCATTGGATAGCGACCCCCACGGTTTATGGGCCCGGAGCGAGAAGAGGGATCC-CTGCCTAGCGGGTTGCTGGTTTCACGCGGCATGG

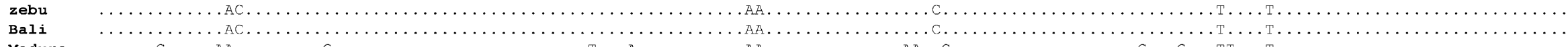

Madura

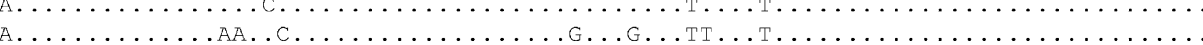

banteng

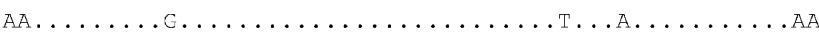

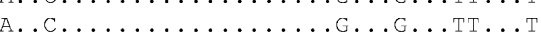

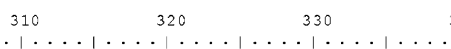

450
.1

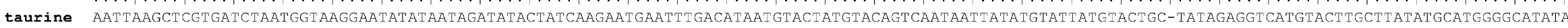

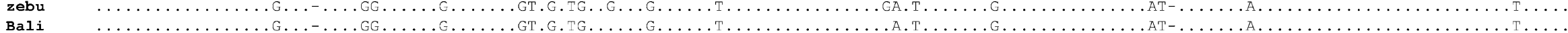

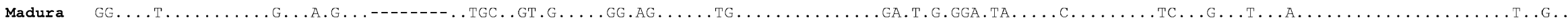

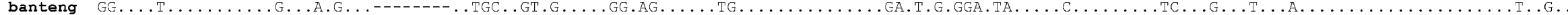

460

taurine ATTTAATGTACTATATACATATTATGTCTTTATTACATTAATGTTATGTAC--ATTAC-_-_-_-_-_._. .

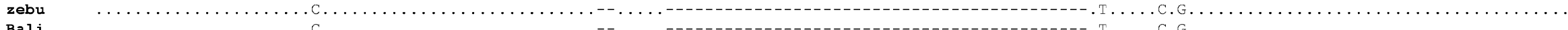

Bali
Madura

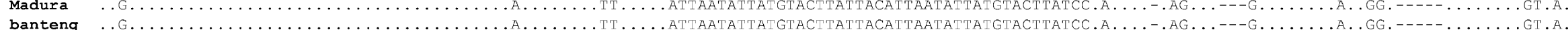

$610 \quad 620$

taurine TAGCT-AGTGGTGTTTGTAA-TALTTGG

$\begin{aligned} & \text { zebu } \\ & \text { Bali }\end{aligned} \ldots \ldots-\ldots \ldots \ldots \ldots \ldots \ldots \ldots \ldots$

Bali
Madura $\quad \ldots \ldots, \ldots \ldots \ldots \ldots \ldots$
ba.

banteng

Figure 1 Alignment of mitochondrial D-loop sequences of zebu (AF1314610), taurine (AF3114579) banteng, Bali and Madura cattle individuals. Dots indicate identical bases and dashes indicate insertions/deletions to optimize the alignment. 


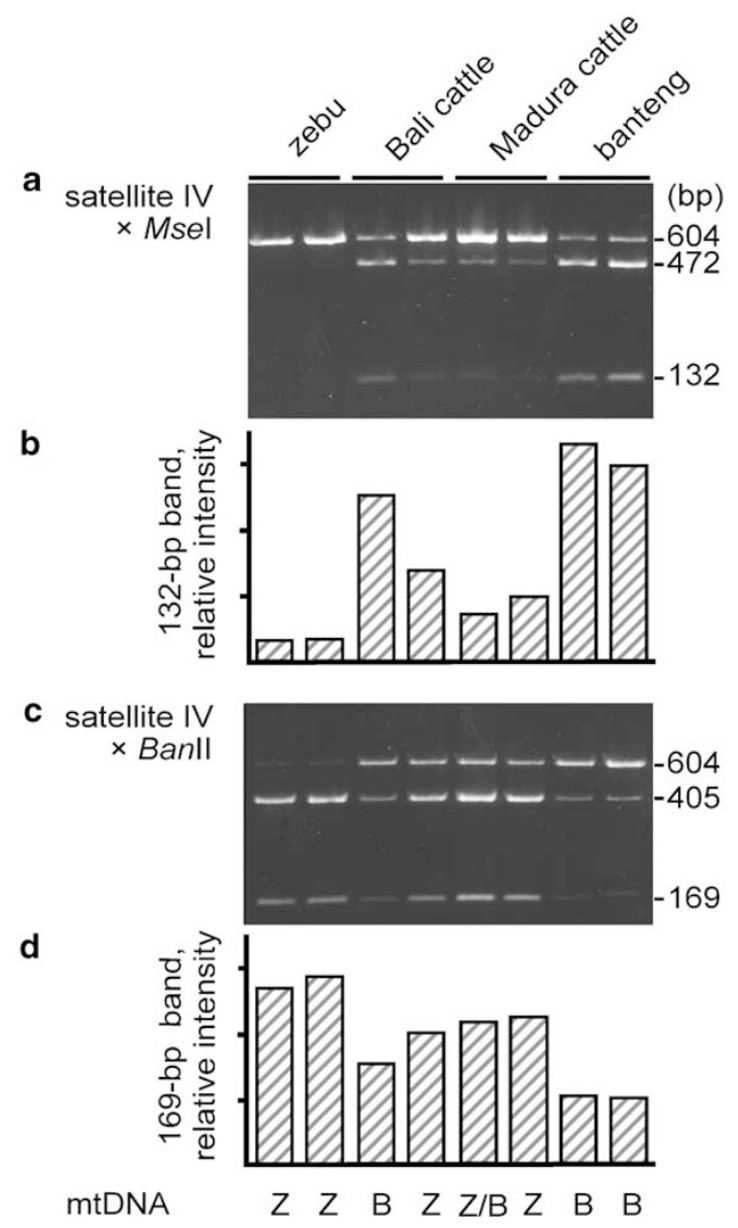

Figure $2(a, c)$ Cleavage patterns of satellite IV PCR fragments. Mitochondrial haplotypes have been determined by restriction analysis of cytochrome $b$ and are indicated with Z (zebu) and B (banteng). (b,d) Relative intensities of the smallest restriction fragments were measured by phosphor imaging of a Southern blot, hybridized to a satellite IV radio-labelled probe and have been recorrected for the total amount of DNA in a lane.

mtDNA is a marker of the maternal lineage, which in cattle corresponds to the history of the herd. So cows of both banteng and zebu origin were used for the breeding of Madura cattle and the Malaysian Bali-cattle population. By SFLP, AFLP and microsatellite typing we analysed the species composition of the nuclear genome, which is also influenced by male-mediated introgression and may also reveal introgression in earlier generations. This may be the result either from intentional upgrading or from natural contact with bulls of another species.

Centromeric satellite DNA (stDNA) is a sensitive marker of species origin (Bachmann et al, 1993; Buntjer et al, 1995, 1998; Jobse et al, 1995; Grenier et al, 1997). As a result of concerted evolution, repeat units of satellite DNA are more similar within than between species (Dod et al, 1989; Waye and Willard, 1989; Elder and Turner, 1995). Related species that share a repeat family can be distinguished by SFLP analysis of repeat variants (Nijman et al, 1999; Nijman and Lenstra, 2001). In the present study, the relative amounts of restriction fragments were quantified by blotting, hybridization and phosphoimaging. In a preliminary experiment, SFLP quantification was successfully achieved by capillary electrophoresis

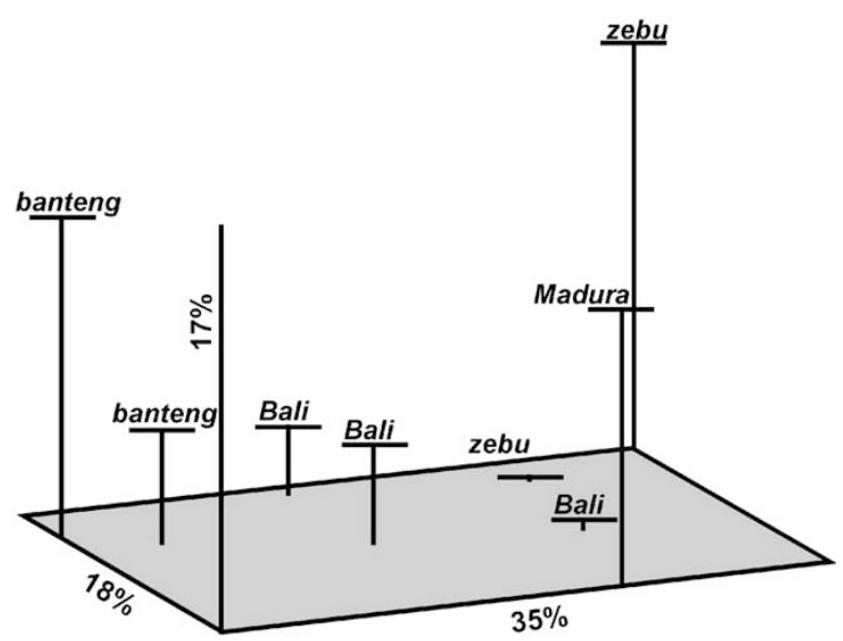

Figure 3 PCO plot of Jaccard similarity values (\% band sharing) as calculated from AFLP data based on 120 polymorphic markers. Percentages indicate amount of variation displayed per axis.

(lab-on-a-chip, Agilent Technologies, Palo Alto, CA, USA). This experiment confirmed the variable species composition of Madura animals, while no zebu introgression was detected in the original Bali samples (unpublished results). The banteng genome contains relatively low amounts of satellite IV (Nijman and Lenstra, 2001), so quantitative analysis of restriction sites may have overestimated the zebu component in our study.

However, the finding of zebu DNA in Madura and Malaysian Bali cattle was also confirmed by AFLP and microsatellite typing. Differences in AFLP patterns correspond to point mutations in or near restriction sites or to insertions and deletions. Depending on the degree of relatedness, AFLP patterns generated by a single primer combination are as informative as the typing of 10-30 SNPs or other bi-allelic markers with negligible effect of co-migration of nonhomologous fragments (Buntjer et al, 2002). AFLP markers have a less dynamic mode of evolution than microsatellites, but still clearly reveal genetic variation. Genetic distances based on band-sharing parameters can be condensed by coordination analysis (Jackson, 1991) to visualize the relative effect of intra- and interspecies variation. A threedimensional principal-coordinate analysis (PCO; Figure 3) shows appreciable differences between animals of the same breed, but suggests that the first dimension (representing about one-third of the total variation) is most informative for detection of the banteng-zebu hybridization.

In addition, we found at most microsatellite loci, characteristic alleles for Bali cattle and banteng. If additional genotyping of Bali and banteng supports the specificity of these alleles, these are potentially valuable for assaying the purity of Bali and other banteng breeds. Most of these alleles are shorter than the zebu-taurine alleles, which is in agreement with the general idea that microsatellite alles are shorter in other species than in the species from which they were originally cloned (Ellegren et al, 1995). Allele frequencies in Bali cattle are intermediate between the frequencies in taurine and indicine cattle and the frequencies in banteng. 


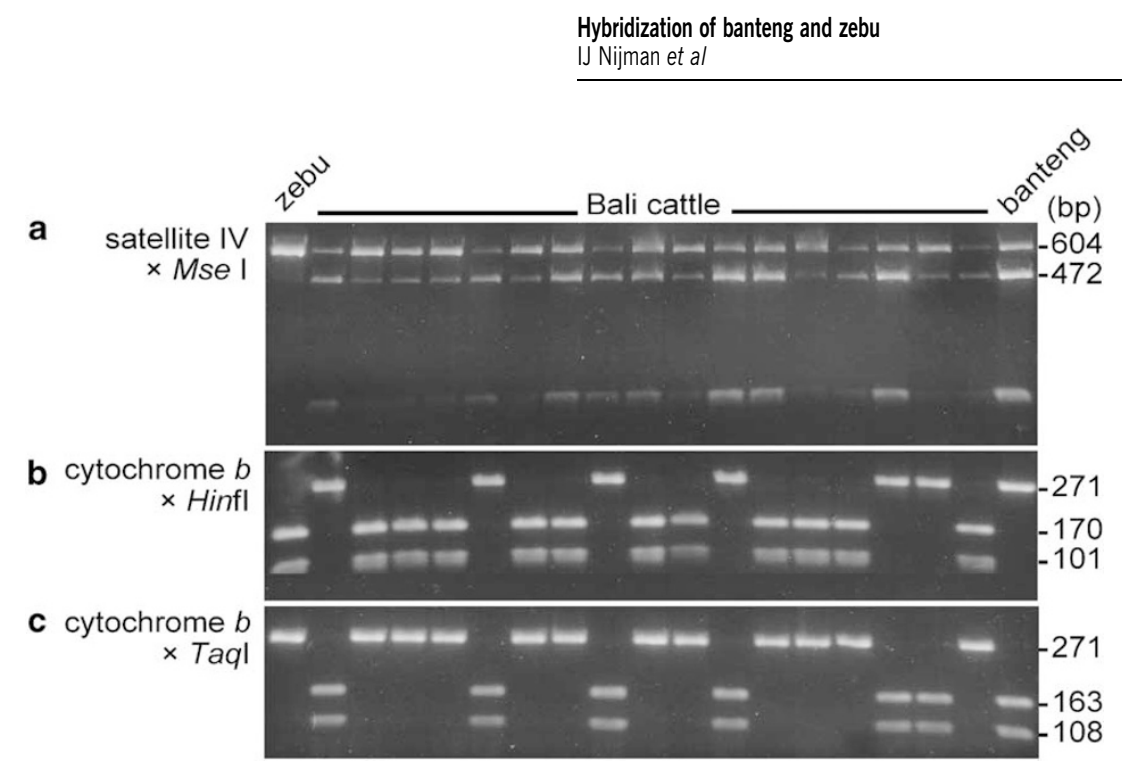

Figure 4 Typing of Malaysian Bali cattle by SFLP and PCR-RFLP of the mitochondrial cytochrome $b$ gene.

Our data, although based on a limited sample size, consistently indicate a hybrid origin of the Madura breed and the Malaysian Bali-cattle population. The molecular tools described in this paper may be applied to a larger panel of samples. This would result in a more comprehensive survey of the unique species composition of Indonesian cattle and contribute to a preservation of their economic and cultural value.

\section{Acknowledgements}

We are grateful for receiving samples or tissue from zebu and taurine cattle from Dr DG Bradley (Trinity College, Ireland) and from banteng from Blijdorp Zoo (Rotterdam, The Netherlands). Nelore and Ongole DNA were provided by Dr Lili Ritz (University of Berne Switzerland). We also thank the Director General of Veterinary Service, the Director of the Veterinary Institute of Kluang and the Manager of Cermin Kiri Farm for facilitating the sampling of the Malaysian Bali cattle. The cooperation of the owners of the Madura animals is gratefully acknowledged. Fruitful discussions with Dr MMJ Udo (Wageningen Agricultural University, The Netherlands) have sparked many ideas. We thank $\mathrm{Mr} \mathrm{W}$ Dorlijn (Agilent) for the use of the capillary electrophoresis apparatus.

\section{References}

Ajmone-Marsan P, Valentini A, Cassandro M, VecchiottiAntaldi G, Bertoni G, Kuiper M (1997). AFLP ${ }^{\mathrm{TM}}$ markers for DNA fingerprinting in cattle. Anim Genet 28: 418-426.

Bachmann L, Schibel JM, Raab M, Sperlich D (1993). Satellite DNA as taxonomic marker. Biol Syst Ecol 21: 3-11.

Bongso TA, Hilmi M, Sopian M, Zulkilfi S (1988). Chromosomes of Gaur cross domestic cattle hybrids. Res Vet Sci 44: 251-254.

Bradley DG, MacHugh DE, Cunningham P, Loftus RT (1996). Mitochondrial diversity and the origins of African and European cattle. Proc Natl Acad Sci USA 93: 5131-5135.

Bradley DG, MacHugh DE, Loftus RT, Sow RS, Hosk CH, Cunningham EP (1994). Zebu-taurine variation in $\mathrm{Y}$ chromosomal DNA: a sensitive assay for genetic introgression in west African trypanotolerant cattle populations. Anim Genet 25: $7-12$
Buntjer JB, Lenstra JA, Haagsma N (1995). Rapid species identification in meat by using satellite DNA probes. $Z$ Lebensm Unters Fors 201: 577-582.

Buntjer JB, Nijman IJ, Zijlstra C, Lenstra JA (1998). A satellite DNA element specific for roe deer (Capreolus capreolus). Chromosoma 107: 1-5.

Buntjer JB, Otsen M (2000). Cross Checker provides computer-assisted marker interpretation. J Agric Genomics 4. http://www.ncgr.org/research/jag/papers99/paper599/ indexp599.html.

Buntjer JB, Otsen M, Nijman IJ, Kuipers MTR, Lenstra JA (2002). Phylogeny of bovine species based on AFLP fingerprinting. Heredity 88: 46-51.

Dod B, Mottez E, Desmarais E, Bonhomme F, Roizes G (1989). Concerted evolution of light satellite DNA in genus Mus implies amplification and homogenization of large blocks of repeats. Mol Biol Evol 6: 478-491.

Elder Jr JF, Turner BJ (1995). Concerted evolution of repetitive DNA sequences in eukaryotes. $Q$ Rev Biol 70: 297-320.

Ellegren H, Primmer CR, Sheldon BC (1995). Microsatellite 'evolution': directionality or bias? Nat Genet 11: 360-362.

Epstein H (1971). The Origin of the Domestic Animals of African Cattle Africana Publishing Cooperation: New York.

Felius M (1995). Cattle Breeds, an Encyclopedia Misset: Doetinchem.

Forsdyke DR (2000). Haldane's rule: hybrid sterility affects the heterogametic sex first because sexual differentiation is on the path to species differentiation. J Theor Biol 204: 443-452.

Frisch JE, Drinkwater R, Harrison B, Johnson S (1997). Classification of the southern African sanga and East African shorthorn zebu. Anim Genet 28: 77-83.

Grenier E, Casagnone-Sereno P, Abad P (1997). Satellite DNA sequences as taxonomic markers in nematodes of agronomic interest. Parasitol Today 13: 398-401.

Hall TA (1999). BioEdit: a user-friendly biological sequence alignment editor and analysis program for Windows 95/98/ NT. Nucleic Acids Symp Ser. 41: 95-98.

Hanotte O, Tawah CL, Bradley DG, Okomo M, Verjee Y, Ochieng J, Rege JE (2000). Geographic distribution and frequency of a taurine Bos taurus and an indicine Bos indicus Y specific allele amongst sub-Saharan African cattle breeds. Mol Ecol 9: 387-396.

Hanotte O, Bradley DG, Ochieng JW, Verjee Y, Hill EW, Rege JE (2002). African pastoralism: genetic imprints of origins and migrations. Science 296: 336-339.

Jackson JE (1991). A User's Guide to Principal Components. Wiley, New York, USA. 
Jobse K, Buntjer JB, Haagsma N, Breukelman HJ, Beintema JJ, Lenstra JA (1995). Evolution and recombination of bovine DNA repeats. J Mol Evol 41: 277-283.

Kemp SJ, Hishida O, Wambugu J, Rink A, Loageri ML, Ma RZ, Da Y, Lewin HA, Barendse W, Teale AJ (1995). A panel of polymorphic bovine, ovine and caprine microsatellite markers. Anim Genet 26: 299-306.

Loftus RT, MacHugh DE, Bradley DG, Sharp PM, Cunningham P (1994a). Evidence for two independent domestications of cattle. Proc Natl Acad Sci USA 91: 2757-2761.

Loftus RT, MacHugh DE, Ngere OL, Balain DS, Badi AM, Bradley DG, Cunningham EP (1994b). Mitochondrial genetic variation in European, African and Indian cattle populations. Anim Genet 25: 265-271.

MacHugh DE, Shriver MD, Loftus RT, Cunningham P, Bradley DG (1997). Microsatellite DNA variation and the evolution, domestication and phylogeography of taurine and zebu cattle. Genetics 146: 1071-1086.

Meyer MR, Höfelen C, Lüthy J, Candrian U (1995). Polymerase chain reaction-restriction fragment length polymorphism analysis: a simple method for species identification in food J AOAC Int 78: 1542-1551.

Namikawa T (1981). Geographic distribution of bovine haemoglobin-beta $(\mathrm{Hbb})$ alleles and the phylogenetic analysis of the cattle in Eastern Asia. Z Tierzüch Züchtsbiol 98: 151-159.

Nijman IJ, Bradley DG, Hanotte O, Otsen M, Lenstra JA (1999). Satellite DNA polymorphisms and AFLP correlate with Bos indicus-taurus hybridization. Anim Genet 30: 265-273.

Nijman IJ, Lenstra JA (2001). Mutation and recombination in cattle satellite DNA. A feedback model for the evolution of satellite DNA repeats. J Mol Evol 52: 361-371.

Payne WJA, Rollinson DHL (1976). Madura cattle. Z Tierzüch Züchtsbiol 93: 89-100.
Rohlf FJ (1993). NTSYS-pc 1.80. Applied Biostatistics Inc.: New York.

Rollinson DHL (1984). Bali cattle. In: Evolution of Domesticated Animals, Mason: IL, Ed: Longman: London and New York.

Sambrook J, Fritsch EF, Maniatis T (1989). Molecular Cloning. A Laboratory Manual. Cold Spring Harbor Laboratory Press: Cold Spring Harbor, USA.

Savelkoul PHM, Aarts HJM, Dijkshoorn L, Duims B, De Haas J, Otsen $\mathrm{M}$ et al (1999). Amplified fragment length polymorphism $\left(\mathrm{AFLP}^{\mathrm{TM}}\right)$, the state of an art. I Clin Microbiol 37: 30833091.

Tumennasan K, Tuya T, YM H, Takase H, Speed RM, Chandley AC (1997). Fertility investigations of the F1 hybrid and backcross progeny of cattle (Bos taurus) and yak (B. grunniens) in Mongolia. Cytogenet Cell Genet 78: 69-73.

Verkaar ELC, Boutaga K, Nijman IJ, Lenstra JA (2001). Differentiation of bovine species in beef by PCR-RFLP of mitochondrial and satellite DNA. Meat Sci 60: 365-369.

Verkaar ELC, Nijman IJ, Beeke M, Hanekamp E, Lenstra JA. (2003). Maternal and paternal lineages in cross-breeding bovine species - the unusual phylogeny of the wisent. Submitted.

Vos P, Hogers R, Bleeker M, Reijans M et al (1995). AFLP: a new technique for DNA fingerprinting. Nucleic Acids Res 23: 44074414.

Ward T, Bielawski JP, Davis SK, Templeton JW, Den JN (1999). Identification of domestic cattle hybrids in wild cattle and bison species: a general approach using mtDNA markers and the parametric bootstrap. Anim Conserv 2: 51-57.

Waye JS, Willard HF (1989). Concerted evolution of alpha satellite DNA: evidence for species specificity and a general lack of sequence conservation among alphoid sequences of higher primates. Chromosoma 98: 273-279. 